Features of communication of adolescents with intellectual disabilities in the interpersonal relations

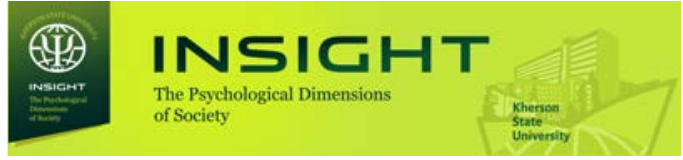

DOI: $10.32999 / 2663-970 X / 2020-3-9$

Link article (Style APA): Drozd, L. V. \& Bystrova, Yu. O. (2020). Features of communication of adolescents with intellectual disabilities in the interpersonal relations. Insight: the psychological dimensions of society, 3, 123-133. DOI: 10.32999/2663-970X/2020-3-9

Link article (Style DSTU 8302: 2015): Drozd, L. V. \& Bystrova, Yu. O. Features of communication of adolescents with intellectual disabilities in the interpersonal relations. Insight: the psychological dimensions of society, 2020, 3, 123-133. DOI: 10.32999/2663-970X/2020-3-9

\title{
Features of communication of adolescents with intellectual disabilities in the interpersonal relations
}

\section{Особливості комунікації підлітків з інтелектуальними порушеннями в міжособистісних стосунках}

Received: April 16, 2020 Accepted: June 08, 2020

\author{
Drozd Lidiia Viktorivna \\ Graduate student \\ Department of Correctional Education \\ Kherson State University, Ukraine \\ Drozdlidiya301091@gmail.com , \\ ORCID0000-00001-5406-2942 \\ Bystrova Yuliia Oleksandrivna \\ Doctor of Psychological Sciences, \\ Full Professor, \\ Department of Correctional Education \\ Kherson State University, Ukraine \\ ceasc.edu@gmail.com, \\ ORCID 0000-0002-1866-0993
}

\author{
Дрозд Лідія Вікторівна \\ аспірантка \\ кафедра корекційної освіти \\ Херсонський державний університет, \\ Україна \\ Drozdlidiya301091@gmail.com , \\ ORCID 0000-00001-5406-2942 \\ Бистрова Юлія Олександрівна \\ доктор психологічних наук, професор \\ кафедра корекційної освіти \\ Херсонський державний університет, \\ Україна \\ ceasc.edu@gmail.com, \\ ORCID 0000-0002-1866-0993
}

\begin{abstract}
The purpose of the research is theoretical justification and development of a step-by-step diagnostic program of the study of communication of adolescents with intellectual disabilities. Methods: theoretical (analysis and generalization of theoretical and methodological fundamentals of the research to identify the status of problem concerned and promising trends of its study) and empirical (psychological and pedagogical experiment to examine verbal statements, emotional responses in a conflict, ways of coping and solving challenging real-life situations, a complex of projective and objective techniques to study a personal assessment, objective reasons of conflicts and features of behavior of adolescents with intellec-
\end{abstract}

\begin{abstract}
Анотація
Метою дослідження $\epsilon$ теоретичне обгрунтування та розробка поетапної діагностичної програми дослідження комунікації підлітків 3 інтелектуальними порушеннями. Методи: теоретичні (аналізування та узагальнення теоретичних та методичних засад дослідження для визначення стану розробленості проблеми й перспективних напрямків її вивчення) та емпіричні (психолого-педагогічний експеримент з метою вивчення мовленнєвих висловлювань, емоційних реакцій у конфлікті, способів подолання та вирішення важких життєвих ситуацій; комплекс проєктивних та об’єктивних методик з метою вивчення суб'єктивної оцінки, об'єктивних причин конфліктів і особливостей поведінки в конфліктних
\end{abstract}


tual disabilities in the conflict situations; comparative analysis of production and perception of statements and frustration situations) research methods. Diagnostic results show that a high level of aggressive statements or inadequate judgments and actions is common to adolescents with intellectual disabilities which correlate with a low level of socialization in the group of same-age peers and choice of behavior strategy during the conflict. It is established that adolescents with intellectual disabilities can master and comprehend communication styles in a specific context as compared to a practical situation. The paper substantiates they are characterized by impulsive actions and statements, difficulties in the catching of implication of statements, their fragmentary understanding, inability to formulate the opinion and to draw a conclusion on the obtained information, the challenges in the establishment of causeand-effect relations, misinterpretation of interlocutor's emotions, the transfer of communication skill to new conditions. Conclusions. The data obtained will be used in developing the program for communication correction of adolescents with intellectual disabilities as a key for their successful socialization, set and implementation of life plans.

Key words: verbal communication, conflicts, interpersonal relations, teenagers, intellectual disabilities, statements, perception.

\section{Introduction}

The topicality of the research is stipulated by the need to establish an organization for the socialization of children with special education needs in higher education institutions. The organization aim is to provide adolescents with intellectual disabilities with psychological aid. Such adolescents face challenging or conflict situations every day, can't establish social ties and thus, they don't look to the future and can't plan out it. The process of socialization of such children is running with particular complications. Intellectual disabilities negatively affect the development of communicative and emotional-volitional realm that complicates the production and perception of information, its analysis, the establishment of cause-and-effect relations and, as a result, it promotes the disturbance of the adoption of moral norms and social behavior and intercepts the setting of life goals and their achievement (Synov, 2019). The scientists mark the disorder of communicative function of speech of this category ситуаціях розумово відсталих підлітків; порівняльного аналізу продукування та сприймання висловлювань у конфліктних та фрустраційних ситуаціях) методи дослідження. Результати діагностики переконують, що підліткам 3 інтелектуальними порушеннями притаманні високий рівень агресивності висловлювань або неадекватної підлеглості у судженнях та діях, що корелює з низьким рівнем соціалізації в групі однолітків, з виборами стратегії поведінки в конфлікті. Встановлено, що підлітки з інтелектуальними порушеннями можуть засвоювати та розуміти стилі спілкування тільки на конкретних прикладах у порівнянні з практичною ситуацією. Обгрунтовано, що для них характерними $\epsilon$ імпульсивні дії та висловлювання, складнощі розуміння прихованого сенсу висловлювань, їх фрагментарне розуміння, неможливість сформулювати судження, зробити висновок з почутої інформації, утруднення встановлення причинно-наслідкових зв'язків, нерозуміння емоції співрозмовника, перенесення навика спілкування в нові умови. Висновки. Отримані дані буде використано при розробці програми корекції комунікації підлітків з інтелектуальними порушеннями як запоруки їх успішної соціалізації, встановлення та реалізації життєвих планів.

Ключові слова: мовленнєва комунікація, конфлікти, міжособистісні стосунки, підлітки, інтелектуальні порушення, висловлювання, сприймання.

\section{Вступ}

Актуальність даного дослідження зумовлена необхідністю організації в закладах спеціальної освіти для соціалізації дітей з особливими освітніми потребами. Сутність цієї організації полягає у психологічній допомозі підліткам з інтелектуальними порушеннями. Такі підлітки щодня опиняються в складновирішуваних або конфліктних ситуаціях, не вміють встановлювати соціальні зв'язки, тому не конструюють своє майбутнє, не вміють його планувати. Процес соціалізації таких дітей відбувається з особливими ускладненнями. Інтелектуальні порушення негативно впливають на стан розвитку комунікативної та емоційно-вольової сфери, що ускладнює продукування та сприймання інформації, ï аналізування, встановлення причинно-наслідкових зв'язків і, як наслідок, сприяє порушенню засвоєння моральних норм і соціальної поведінки, стає перешкодою в постанові життєвих цілей та їх досягненні (Синьов, 2019). 
Features of communication of adolescents with intellectual disabilities in the interpersonal relations

of children is manifested in the inability to percept the verbal information in full and to formulate a statement (Pevzner, 1959), (Boyle et al., 2013).

Taking into account the negative influence of the disorders of verbal communication on the social adaptation of adolescents with intellectual disabilities, the authors highlight the relevancy of the problem under consideration for special psychology. Particular attention needs to be paid to determining the causes, dynamics of production and perception of statements during interpersonal communication of adolescents to identify opportunities and methods of correctional influence to establish social contacts for the implementation of life plans and successful integration into society.

\section{The purpose and the research issue}

The purpose of the article is theoretical justification and development of a step-by-step diagnostic program for the study of communication of adolescents with intellectual disabilities to identify the opportunities and methodologies of correctional influence in order to develop skills to establish social connections necessary for life plans.

\section{Methodology}

The methodological framework of the research consists of the theory of socialization as a process of assimilation of moral norms and shared social behavior by a personality (Yu. Bystrova, V. Synov, M. Sheremet et al.); the theory of self-regulation of activities and behavior of a personality (S. Maksymenko, I. Popovych et al.).

Research methods. The authors use empirical methods to cover the whole range of problems:

1) to study the subjective assessment, personal reasons for difficulties in forming social relations and setting future goals of adolescents with intellectual disabilities;

2) to study the statements, emotional responses in the interpersonal communication, ways of coping and solving challenging real-life situations.

Adolescents with intellectual disabilities find it difficult to perceive many formulations of personal questionnaires. In this regard, the authors select tests which are easily comprehended both by adolescents from general secondary and special schools. Before the diagnosis, adolescents were interviewed to identify the vision of their future,

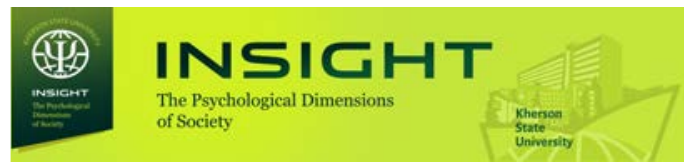

Вчені відзначають, що порушення комунікативної функції мовлення в цієї категорії дітей простежується як нездатність повноцінно сприймати вербальну інформацію, неможливості створювати висловлювання (Певзнер, 1959; Boyle et al., 2013).

Ураховуючи негативний вплив порушень мовленнєвої комунікації на соціальну адаптацію підлітків з інтелектуальною недостатністю, підкреслено актуальність проблеми дослідження для спеціальної психології. Особливої уваги потребують питання визначення причин, динаміки продукування й сприймання висловлювань у міжособистісній комунікації підлітків для визначення можливостей і методик корекційного впливу з метою налагодження соціальних контактів для реалізації життєвих планів і успішної інтеграції в соціум.

Мета статті - теоретично обгрунтувати та розробити поетапну діагностичну програму дослідження комунікації підлітків з інтелектуальними порушеннями для визначення можливостей і методик корекційного впливу 3 метою формування вмінь встановлювати соціальні зв'язки, необхідні для реалізації життєвих планів.

\section{Методологія}

Методологічну основу дослідження склали: теорія соціалізації як процесу засвоєння особистістю моральних норм і соціально схваленої поведінки (Ю. Бистрова, В. Синьов, М. Шеремет та ін.); теорія саморегуляції діяльності і поведінки особистості (С. Максименко, I. Попович та ін.).

\section{Методи дослідження:}

1) вивчення суб'єктивної оцінки, об'єктивних причин складнощів у формуванні соціальних зв'язків та плануванні майбутніх цілей у підлітків з інтелектуальними порушеннями;

2) вивчення висловлювань, емоційних реакцій у міжособистісному спілкуванні, способів подолання та вирішення важких життєвих ситуацій.

Підлітки з інтелектуальними порушеннями досить важко сприймають багато формулювань особистісних опитувальників. У зв'язку з цим добиралися ті тести, які однаково легко сприймалися підлітками з загальноосвітніх і спеціальних шкіл. Перед початком діагностики з підлітками проводилися бесіди для визначення їx розуміння власного майбутнього, міжособистісних стосунків у ньому, вміння оцінювати взаємо- 
interpersonal relationships within it, the ability to assess relationships with peers and adults based on the verbal statements of the opponent. To study the production of statements in the context of frustration and the ways of overcoming the difficulties, it is used Thomas-Kilmann Conflict Mode Instrument (TKI) adopted by the authors (Bystrova, 2019), Phillips's School Anxiety Test (Bystrova, 2018) and S. Rosenzweig's Picture Association Method (Lukyn, 1993). To diagnose the understanding of the implication of statements, the correlation of emotions and statements of an interlocutor, perception of the statement by adolescents with intellectual disabilities, the method of T. Illiashenko "The comprehension of a story with implication" is used (Illiashenko, 2011).

\section{Participants}

120 adolescents who study at the special education institutions and 120 adolescents of general secondary schools of Kherson, Kyiv, Cherkasy and Ternopil regions of Ukraine joined the experiment. The experiment involved 60 preadolescents with intellectual disabilities of grades 5-7 and 60 adolescents of grades 8-9.

\section{Results and discussion}

The research was conducted from 2017 to 2019 and included two stages. The first stage determines the central problems associated with interpersonal communication of adolescents with intellectual disabilities, identifies specific communicative situations triggering conflicts and special aspects of their behavior. Based on the analysis of psychological literature, the authors select methods.

Experimental groups were identified and a confirmatory experiment was performed at the second stage. The second stage determines experimental groups, runs ascertaining experiment. It aims to study the features of verbal communication of adolescents with mental disabilities during inter-personal communication.

Keeping in mind general concepts, one of the tasks is to establish subjective psychological preconditions for the emergence of difficulties in thesetting life goals, establishment of social relations for their achievement of adolescents with intellectual disabilities (Lozhkin, 2002). The diagnostic results show that inadequate production відносини з однолітками та дорослими на основі мовленнєвих висловлювань опонента. Для вивчення продукування висловлювань у ситуації фрустрації та способів подолання труднощів використовувався адаптований нами варіант методики М. Томаса (Бистрова, 2019), тест шкільної тривожності Філіпса ( Бистрова, 2018) та метод малюнкової асоціації С. Розенцвейга (Лукин, 1993). Для діагностики розуміння прихованого сенсу висловлювань, співвідношення емоції та висловлювання співрозмовника, сприймання висловлювання підлітками з інтелектуальними порушеннями використовувалася методика Т. Ілляшенко «Розуміння змісту оповідання з підтекстом» (Ілляшенко, 2001).

\section{Учасники}

В експерименті взяли участь 120 підлітків, що навчаються в спеціальних закладах освіти, і 120 підлітків загальноосвітніх шкіл Херсонської, Київської, Черкаської та Тернопільської областей України. В експерименті брало участь 60 молодших підлітків 3 інтелектуальними порушеннями 5-7 класів і 60 старших підлітків 8-9 класів.

\section{Результати та дискусія}

Дослідження проводилося впродовж 20172019 років і поєднувало два етапи. На першому етапі було визначено основні проблеми, пов'язані з міжособистісним спілкуванням підлітків 3 інтелектуальними порушеннями, виявлено характерні комунікативні ситуації, що викликають конфлікти і особливості поведінки в них. На основі аналізування психологічної літератури здійснювався підбір методик.

На другому етапі були визначені експериментальні групи, проводився констатувальний експеримент. Його основним завданням стало вивчення особливостей мовленнєвої комунікації підлітків з інтелектуальними порушеннями в міжособистісному спілкуванні.

Виходячи із загальних концепцій, одним із завдань було встановлення суб'єктивних психологічних передумов виникнення складнощів у постановці життєвих цілей, встановленні соціальних зв'язків для їх досягнення у підлітків 3 інтелектуальними порушеннями (Ложкин, 2002). За результатами діагностики було встановлено, що найчастіше причиною конфліктної або агресивної поведінки підлітків з інтелектуальними порушеннями стає порушене продукування та сприймання висловлювань, а також нерозуміння емоцій іншої сторони. Це пов'язано $з$ більш пізнім формуванням особистості 
Features of communication of adolescents with intellectual disabilities in the interpersonal relations

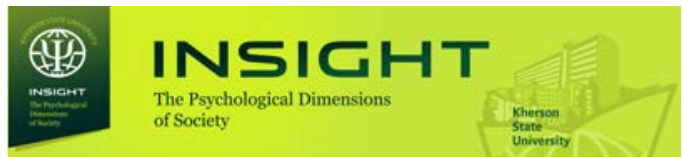

and interpretation of statements, as well as misunderstanding of emotions of the other party, are the most common cause of conflict or aggressive behavior of adolescents with intellectual disabilities. The before mentioned fact is connected with more late personality development of an adolescent of the special school compared to an adolescent of general secondary school. Until high school, an adolescent with intellectual disabilities begins to realize that he is unsuccessful compared to other peers and feels his personal and social inferiority. This point hinders him from achieving success in the interpersonal relations and activity which attracts the adolescent and thus, increases anxiety in this regard $(p<0,01)$.

The research demonstrates that in interpersonal relations, verbal communication plays a big role in the formation of the positive or destructive behavior of adolescents with mental disabilities (Bystrova, 2017; 2019). Under intellectual disabilities, a child can acquire and comprehend communication styles in a specific context. For this very reason, verbal communication is a basis that an adolescent assesses and grasps the situation. Weak capability to independently draw conclusions from any statements leads to the fact that the adolescent absorbs the comments in comparison with the practical situation. Consequently, the authors find out that causes of conflicts, including domestic one, are parental lack of attention, use of conflictogenic verbal manifestations (irrevocability of statements, aggression, didacticism, ignoring). According to the diagnostic, a choice of behavior models of adolescents with mental disabilities also depends on personal qualities developed within the family. It forms and consolidates some patterns of verbal communication and destructive behavior: dependent (adjustment under the conditions of conflict interaction or frustration), alienated (conflicts avoidance, resistance to render decisions, a lack of skill to work in a team and under the supervision) and aggressive (destructive rivalry) with the use of practically assimilated vocabulary.

The next stage of the research determines the dependence of adolescents' behavior on their age peculiarities (negative and positive period of puberty age), gender differences and the level of development of communication interpersonal skills. It is found out through the method of comparative analysis of production and perception підлітка спеціальної школи порівняно $з$ підлітком загальноосвітньої школи. Підліток з інтелектуальними порушеннями до старших класів починає усвідомлювати, що $є$ неуспішним у порівнянні з іншими однолітками, відчуває власну та суспільну неповноцінність. Це усвідомлення заважає йому досягти успіхів у міжособистісних стосунках та діяльності, а отже, збільшує тривожність з цього приводу $(\mathrm{p}<0,01)$.

Дослідження показало, що величезну роль у формуванні позитивної чи деструктивної поведінки підлітків з інтелектуальними порушеннями відіграє мовленнєва комунікація в міжособистісних стосунках (Бистрова, 2017; 2019). При інтелектуальних порушеннях дитина може засвоювати та розуміти стилі спілкування тільки на конкретних прикладах, тому саме вербальна комунікація є основою для того, щоб підліток оцінив та сприйняв ситуацію. Слабка здатність самостійно робити висновок з будь-яких суджень приводить до того, що підліток сприймає судження у порівнянні з практичною ситуацією. Так нами було встановлено, що до причин, які викликають конфлікти, зокрема в сім'ї, належать знехтування підлітка батьками, використання мовленнєвих конфліктогенів (безапеляційність висловлювань, агресивність, повчання, ігнорування). За результатами діагностики було з'ясовано, що вибір поведінки підлітків з інтелектуальними порушеннями також залежить від особистісних якостей, вихованих у родині, саме там йде формування та закріплення окремих стереотипів мовленнєвої комунікації та деструктивної поведінки: залежної (пристосування в умовах конфліктної взаємодії або фрустрації), відокремленого (уникнення конфліктів, небажання приймати рішення, невміння працювати в команді та під керівництвом) та агресивного (деструктивне суперництво) з використанням засвоєної на практиці відповідної лексики.

На наступному етапі дослідження було визначено залежність поведінки підлітків від їх вікових особливостей (негативна та позитивна стадія пубертатного віку), гендерних відмінностей та рівня розвитку комунікативних навиків міжособистісного спілкування. Це з'ясовувалося методом порівняльного аналізу продукування та сприймання висловлювань у конфліктних та фрустраційних ситуаціях різних груп підлітків (підлітки з інтелектуальними порушеннями та підлітки з нормотиповим розвитком).

Було виявлено, що підлітки загальноосвітніх шкіл більш здібні до співробітництва в конфліктних ситуаціях $(\mathrm{p}<0,01)$. А у підлітків спеціальних шкіл, у силу ускладнення сприй- 
of statements in conflict and frustration situations of various groups of adolescents (adolescents with mental disabilities and neurotypical adolescents).

The authors clear up that adolescents of general secondary schools are more capable of cooperating in conflict situations $(\mathrm{p}<0,01)$. And adolescents of special schools, because of complicated perception of statements and disorder to conclude on any comments, backwardness of control over own actions, misunderstanding of cause-and-effect relations due to failure to assess the situation adequately, mainly manifest destructive forms of behavior during the conflict: passive - avoidance, adjustment, and active - rivalry. Without relevant correctional work, the amount of constructive ways - cooperation and compromise - doesn't advance from early to late adolescence $(t=0,06$; $\mathrm{p}=0,95$ i $\mathrm{t}=-1,52 ; \mathrm{p}=0,13)$. According to diagnostic results, it is established that adolescents with mental disabilities use virtually the same strategies as neurotypical adolescents, except the cooperation strategy, which is not applied by adolescents with mental disabilities. This fact is conditioned by their inability to accept and analyze arguments of the other party and key features of the situation as a whole. The weak cause-andeffect relations don't allow them to express their opinion properly and in a well-argued manner.

Moreover, the conducted researches elucidate qualitative changes. Observations and answers to the questions under coping strategies show "... about $40 \%$ of interviewed adolescents with intellectual disabilities try to regulate their state by scuffles $(r=0,61)$, verbal aggression $(r=0,60)$, property damage $(\mathrm{r}=0,38)$, cry $(\mathrm{r}=0,63)$, abnormal behavior $(r=0,45)$.The rivalry of adolescents with mental disabilities often means disconsolate cry, not the social activity for pursuing a goal that is peculiar to the norm" (Bystrova, 2017: 43). It refers to immature personality, the self-consciousness of such adolescents as well as to the failure of correlation of personal expectations with requirements of the social environment for this category of children (Popovych, 2017). Adaptation strategy is manifested in the striving to keep relations, readiness to acquiesce and to knuckle underdespite personal interests". The quantitative indicator of adaptation of adolescents from general secondary and special schools in the conflict is equal. However, the observations indicate the qualitative differences of this feature in different groups. In мання висловлювань та порушення можливості робити висновки з будь-яких суджень, недорозвиненості контролю над своїми діями, нерозуміння причинно-наслідкових зв'язків, через неможливість адекватно оцінити ситуацію, переважають деструктивні форми поведінки в конфлікті: пасивні - уникнення, пристосування та активні - суперництво. Без певної корекційної роботи кількість конструктивних способів співробітництва й компромісу - від молодшого до старшого підліткового віку не збільшується (t=0,06; p=0,95 i t=-1,52; p=0,13). Стратегії поведінки підлітків у конфлікті з віком практично не змінюються, про це свідчать і показники $(\mathrm{t}=-1,59, \mathrm{p}=0,11)$. За результатами діагностики встановлено, що підлітки 3 інтелектуальними порушеннями використовують майже такі самі стратегії поведінки, як підлітки з нормотиповим розвитком, за винятком стратегії співробітництва, яку практично не використовують підлітки з інтелектуальними порушеннями. Це зумовлено їх неспроможністю прийняти та проаналізувати аргументи іншої сторони конфлікту та суттєві ознаки ситуації в цілому. Слабкість причинно-наслідкових зв'язків не дозволяє їм правильно та аргументовано висловлювати власну думку.

Крім того, проведені дослідження висвітили якісні зміни. Спостереження та відповіді на запитання анкети Копінг-стратегій показали, що «...близько 40,0\% опитуваних підлітків з інтелектуальними порушеннями намагаються регулювати свій стан бійками $(\mathrm{r}=0,61)$, вербальною агресією $(\mathrm{r}=0,60)$, псуванням речей $(\mathrm{r}=0,38)$, криком (r=0,63), неадекватною поведінкою $(\mathrm{r}=0,45)$. Суперництво у підлітків з інтелектуальними порушеннями часто виявляється як крик відчаю, а не як соціальна активність у досягненні мети, що властива нормі» (Бистрова, 2017: 43). Це вказує на несформованість особистості, самосвідомості таких підлітків, а також на неспіввіднесеність особистісних очікувань та вимог соціального оточення до цієї категорії дітей (Попович, 2017). Стратегія пристосування виражається в прагненні зберегти стосунки, готовності поступитися та підкоритися всупереч власним інтересам». Кількісний показник пристосування в конфлікті в підлітків загальноосвітніх і спеціальних шкіл не відрізняється. Однак спостереження показують якісні відмінності цієї ознаки в різних групах. У підлітків з інтелектуальними порушеннями це пов'язано з недорозвиненістю вольової сфери, невмінням відстоювати власну точку зору, продукувати висловлювання, 3 вираженою конформністю 
Features of communication of adolescents with intellectual disabilities in the interpersonal relations

adolescents with mental disabilities, it is caused by immature of volition, failure to assert the view, marked conformity and dependency, amenability to suggestion. Thus, adolescences with intellectual disabilities are more likely to choose the adaptation strategy in the conflict situation and when they talk about the feeling of fear to be inconsistent with others' expectations $(r=0,30)$ and the fear of relations with teachers $(r=0,31)$. Neurotypical adolescents often take a passive position of subjection based on moral norms. Avoidance of challenging situations and situations of independent decision-making designates the passive social attitude of adolescents with mental disabilities. The primary cause is undeveloped cause-effect relation along with forced subjection to the requirements of others. "Up to high school of the special school, adolescences have a tendency to reduce the social passive forms of response in the conflict situations (avoidance, adoption) but it is minimum ( $\mathrm{t}=1,93, \mathrm{p}=0,056$; $t=1,68 ; p=0,095)$. Consequently, a high level of destructive forms of behavior in the conflict is a result of a low level of adolescences' adaptation to the social environment (according to methodology of S. Rosenzweig, GCR $=33,3 \%$ in the group of junior adolescents and $=42,0 \%$ in the group of senior adolescents)" (Bystrova, 2017: 48).

During the study, the authors also draw attention to the gender aspect of differences in the behavior of adolescents with mental disabilities in the context of challenging situations of frustration or independent decision-making. Girls more often use socially approved behavior patterns and thus, are subjected to adaptation and conflict avoidance. At the same time, they take responsibility for the situation that reflects the predominance of intropunitive reactions of female behavior $(p<0,01)$. Boys are more likely to express open rivalry and tend to shift responsibility and blame on the opponent (predominance of self-protective reactions) $(\mathrm{p}<0,01)$.

Answers to the adapted Thomas-Kilmann Instrument are thoroughly checked with the observation protocols of behavior and verbal rhetoric of adolescents in conflict situations. Under the observation, the scheme based on S. Rosenzweig's principles of critical or frustration situation is used (Lukyn, 1993).

The findings on statements according to S. Rosenzweig make it possible to conclude on

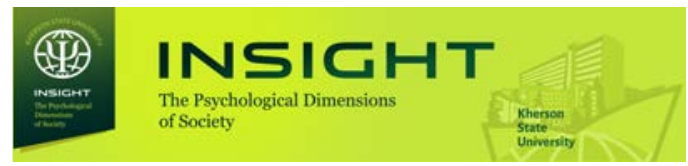

та підлеглістю, навіюваністю у судженнях. Так, підлітки 3 інтелектуальними порушеннями частіше обирають стратегію пристосування в конфліктній ситуації, коли говорять про відчуття страху невідповідності очікуванням оточуючих $(\mathrm{r}=0,30)$ і страху стосунків з учителями $(\mathrm{r}=0,31)$. Підлітки з нормотиповим розвитком часто займають пасивну позицію підкорення, виходячи з моральних норм. Уникнення складних ситуацій та ситуацій прийняття самостійного рішення вказують на пасивну соціальну позицію підлітків з інтелектуальними порушеннями. Основна причина тут - несформованість причинно-наслідкових зв'язків разом з вимушеним підкоренням вимогам оточуючих. «До старших класів спеціальної школи в підлітків намічається тенденція до зменшення соціально пасивних форм реагування в ситуації конфлікту (уникнення, пристосування), але вона незначна $(\mathrm{t}=1,93, \mathrm{p}=0,056 ; \mathrm{t}=1,68 ; \mathrm{p}=0,095)$. Отже, високий рівень деструктивних форм поведінки в конфлікті зумовлений низьким рівнем адаптації підлітків до соціального оточення (за методикою C. Розенцвейга, у групі молодших підлітків GCR = 33,3\%, старших = 42,0\%)» (Бистрова, 2017: 48).

У дослідженні ми звернули увагу на гендерний аспект відмінностей у поведінці підлітків з інтелектуальними порушеннями у складних ситуаціях фрустрації або прийняття самостійного рішення. Дівчата частіше використовують соціально схвалену поведінку, а тому більш схильні до пристосування та уникнення в конфлікті, у той же час беруть усю відповідальність за ситуацію на себе, про що свідчить переважання інтрапунітивних реакцій у поведінці дівчат $(\mathrm{p}<0,01)$. Хлопці частіше виявляють відкрите суперництво та схильні перекладати всю відповідальність і провину на опонента (переважання самозахисних реакцій) $(\mathrm{p}<0,01)$.

Відповіді, отримані за адаптованою методикою К. Томаса, ретельно звірялися з протоколами спостережень за поведінкою та мовленнєвими висловлюваннями підлітків у конфліктних ситуаціях. При спостереженні була використана схема, заснована на принципах критичної або фрустраційної ситуації С. Розенцвейга (Лукин, 1993).

Отримані результати висловлювань за методикою С. Розенцвейга дозволили зробити висновки про вибір способу комунікації підлітка з інтелектуальними порушеннями як про результат його соціалізації. Підліток вирішує складну життєву ситуацію, виходячи з норм, які він засвоїв на практичному досвіді у родині, школі, з оточуючими однолітками та дорослими, використо- 
a choice of a communication method of an adolescent with mental disabilities as a result of his socialization. The adolescent solves a challenging life situation relying on the norms he has learned in practice in the family, school, with peers and adults, uses available behavioral stereotypes but very often cannot transfer the established behavior skills to new conditions and begins to worry and show aggression in this regard. Based on the production of statements and independent conclusions of adolescents with intellectual disabilities proceeding from their judgments, one can refer to their mechanisms of socialization for coping conflict situations - active and attacking (aggressive or constructive) and passive-defensive (dependent or responsible). Given intellectual disability, adolescents have a lack of well-mastered moral norms, control over their actions and conduct; they don't take the situation adequately. Thus, one can note mainly impulsive reactions to all that is happening.

Adolescents with intellectual disabilities are characterized by a high level of aggressiveness of statements or inadequate subordination in statements and actions that correlates with a low level of socialization among peers. Average indicator of adaptation to the social environment according to S. Rosenzweig's instrument is as follows: GCR $=33,3 \%$ in the group of junior adolescents and $=42,0 \%$ in the group of senior adolescents. These children demand solutions to their problems from others, which is a feature of inadequate self-esteem and complicates interpersonal contact with other adolescents.

The authors mark that in the group of adolescents from general education schools, GCR $=51,0 \%$ in junior school and $69,0 \%$ in high school. At the same time, neurotypical adolescents often conflict but explain that a refusal of rivalry may be interpreted as giving up and way for defeat. Moreover, in the context of critical or conflict situations, adolescents of general secondary schools tend to self-defense (E) and contentious-critical (NP) reaction (search for a solution, constructive decision, the aspiration to meet needs, and mandatory solution of the situation).

The frequent choice of inadequate behavioral strategies in situations of conflict or frustration can also be explained by a low level and features of communication of adolescents with intellectual disabilities (table 1). Therefore, the research вує доступні йому стереотипи поведінки, але дуже часто не може перенести сформовані навички поведінки в нові умови та починає тривожитися та проявляти 3 цього поводу агресію. На підставі продукування висловлювань та самостійних висновків підлітків з інтелектуальними порушеннями на основі власних суджень можна говорити про їх механізми соціалізації в подоланні конфліктних ситуацій - активно-наступальні (агресивні або конструктивні) і пасивно-оборонні (підлеглі або відповідальні). Якщо в силу інтелектуальних порушень у підлітків моральні норми недостатньо засвоєні, не розвинений контроль над своїми діями і вчинками, ситуація не сприймається ними адекватно, то можна говорити в більшій мірі про імпульсивні реакції на те, що відбувається.

Підліткам 3 інтелектуальними порушеннями притаманні високий рівень агресивності висловлювань або неадекватної підлеглості у судженнях та діях, що корелює з низьким рівнем соціалізації в групі однолітків. Середній показник адаптації до свого соціального оточення за методикою С. Розенцвейга в групі молодших підлітків GCR = 33,3\%, старших підлітків $=42,0 \%$. Ці діти вимагають вирішення власних проблем від оточуючих, що дуже часто $€$ ознакою неадекватної самооцінки і ускладнює міжособистісні контакти з іншими підлітками.

Відзначимо, що в групі підлітків із загальноосвітніх шкіл GCR = 51,0\% в молодших класах i 69,0\% - в старших. При цьому підлітки з нормотиповим інтелектуальним розвитком теж досить часто конфліктують, але пояснюють це тим, що відмова від суперництва може бути сприйнята як поступка та шлях до поразки. Крім того, в критичних і конфліктних ситуаціях підлітки загальноосвітніх шкіл частіше вибирають самозахисну (Е) та завзято-вирішальну (NP) реакцію (пошук виходу, конструктивного рішення, бажання домогтися задоволення потреб, не залишати ситуацію невирішеною).

Частий вибір неадекватних стратегій поведінки у ситуаціях конфлікту або фрустрації можна пояснити також низьким рівнем та особливостями комунікації підлітків 3 інтелектуальними порушеннями (табл. 1). Так, за результатами дослідження (Ілляшенко, 2001), встановлено, що тільки 61,0 \% молодших та 68,0 \% старших підлітків повністю, а не фрагментарно розуміють сенс зверненого мовлення, при цьому всього 3,0% і 5,0% підлітків, відповідно, розуміють прихований сенс висловлювання. I з роками ситуація практично не змінюється (табл. 1). 
Features of communication of adolescents with intellectual disabilities in the interpersonal relations

results (Illiashenko, 2001) show that 61,0\% of junior and $68,0 \%$ of senior adolescents fully, rather than fragmentarily, understand the meaning of addressed speech, while only $3,0 \%$ and $5,0 \%$ of adolescents (respectively) catch the implication of the statement. This situation has little changed through the years (table 1).

Moreover, more than a third of adolescents do not identify the emotion of the interlocutor and his statements (junior adolescents-- 32.0\% and senior adolescents $-37.0 \%$ ), act and react impulsively (junior adolescents-- $76.0 \%$ and senior adolescents --71.0\%).

Thus, the choice of a behavioral pattern in the conflict by adolescents with mental disabilities depends on the level of their socialization and is caused by the available conflict balance between internal and external regulators of behavior. They are characterized by impulsive actions and statements, complexity in the understanding of implicative statements, their fragmentary comprehension, inability to formulate a standpoint, to draw a conclusion from heard comments, difficulty in the establishment of cause-effect relations, misinterpretation of an interlocutor's emotions, and transfer of skill to the new conditions.

\section{Conclusions}

As a result, the authors can conclude that one of the most important elements for the socialization of adolescents with intellectual needs is

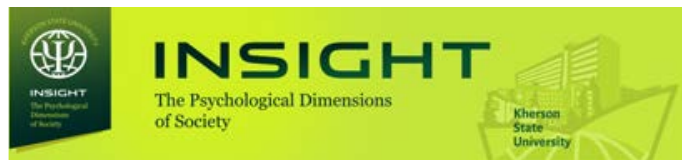

Крім того, більш ніж третя частина підлітків не співвідносять емоцію співрозмовника та його висловлювання $(32,0$ \% молодші підлітки, 37,0 \% - старші), діють і відповідають практично завжди імпульсивно (76,0% молодші підлітки, 71,0 \% - старші).

Таким чином, вибір поведінки в конфлікті підлітками з інтелектуальними порушеннями залежить від рівня їх соціалізації та зумовлений наявним конфліктним співвідношенням між внутрішніми та зовнішніми регуляторами поведінки. Для них характерними $€$ імпульсивні дії та висловлювання, складнощі розуміння прихованого сенсу висловлювань, їх фрагментарне розуміння, неможливість сформулювати судження, зробити висновок з почутої інформації, утруднення встановлення причинно-наслідкових зв'язків, нерозуміння емоції співрозмовника, перенесення навичок спілкування в нові умови.

\section{Висновки}

Таким чином, можемо зробити висновок, що одним з важливих елементів соціалізації підлітків з інтелектуальними порушеннями $є$ корекція їх комунікації в міжособистісних стосунках, з метою формування свідомого розуміння спрямованого мовлення, запобігання використанню мовленнєвих конфліктогенів, провокуючих висловлювань і дій, що дозволить встановлювати корисні соціальні зв'язки, працювати в команді, володіти м'якими технологіями самопрезентації. Ці соціальні компетенції дозволять підліткам з інтелектуальними порушен-

Table 1. Communication features of adolescents with intellectual disabilities (\%)

Таблиця 1. Особливості комунікації підлітків з інтелектуальними порушеннями (\%)

\begin{tabular}{|c|c|c|}
\hline $\begin{array}{l}\text { Criteria } \\
\text { Критерії }\end{array}$ & $\begin{array}{l}\text { Junior adolescents } \\
\text { Молодші підлітки }\end{array}$ & $\begin{array}{c}\text { Senior adolescents } \\
\text { Старші підлітки }\end{array}$ \\
\hline $\begin{array}{l}\text { Understanding of the addressed statements } \\
\text { Розуміє сенс зверненого мовлення }\end{array}$ & 61,0 & 68,0 \\
\hline $\begin{array}{l}\text { Understanding of the implication of the statement } \\
\text { Розуміє прихований сенс висловлювання }\end{array}$ & 3,0 & 5,0 \\
\hline $\begin{array}{l}\text { Identification and literal perception of an opponent's comment } \\
\text { and emotion } \\
\text { Співвідносить та адекватно розуміє висловлювання та } \\
\text { емоцію опонента }\end{array}$ & 32,0 & 37,0 \\
\hline $\begin{array}{l}\text { Accuracy of conclusions based on the personal judgment } \\
\text { Правильно робить висновок на основі власного судження }\end{array}$ & 7,0 & 11,0 \\
\hline $\begin{array}{l}\text { Response based on the personal conclusion } \\
\text { Відповідає згідно з власним висновком }\end{array}$ & 24,0 & 29,0 \\
\hline $\begin{array}{l}\text { Impulsiveness of response } \\
\text { Відповідає імпульсивно }\end{array}$ & 76,0 & 71,0 \\
\hline
\end{tabular}


the correction of their communication in the interpersonal relations to form a conscious understanding of the addressed speech, prevention of the use of conflictogenic verbal manifestations, provocative statements and actions that makes it possible to establish useful social relations, work in the team, mastersoft technologies of self-presentation. These social competencies permit adolescents with intellectual disabilities to integrate into the society and to create the future.

Based on the research findings, the authors determine the ways and conditions for the performance of correctional activities, including studying programs with elements of training and drama games, real-life cases to form social competence and socially approved behavior of adolescents with intellectual disabilities.

The conducted research doesn't cover all aspects of the problem. The issues of development of communicative skills of children with intellectual disabilities, correction of features of their behavior need further study. Moreover, the study should focus on the development of the skill of children with mental disabilities to analyze the essential features and personal socially approved beliefs based on the conclusions on any statements for life goal-setting and successful socialization in the society.

\section{References}

Boyle, W., Lindell, A., \& Kidd, E. (2013). Investigating the Role of Verbal Working Memory in Young Children's Sentence Comprehension. Language Learning, 63(2), 211-242. DOI: 10.1111/ lang.12003

Bozhovich, L. I. (1995). Selected psychological works. Problems of personality formation / Ed. D. I. Feldstein. Moscow: International Pedagogical Academy.

Bystrova, Y. O. (2017). Ensuring continuity in the process of professional and labor socialization of persons with intellectual disabilities: a monograph. Luhansk: Luhansk Taras Shevchenko National University Publishing House.

Bystrova, Y. O. \& Kovalenko, V. E. (Ed.). (2018). Special psychological and pedagogical diagnostics. Kharkiv: Maidans.

Choi, Y., \& Mazuka, R. (2003). Young Children's Use of Prosody in Sentence Parsing. Journal of Psycholinguist Research, 32 (2), 197-217. DOI: 10.1023/A:1022400424874

Illiashenko, T. D, Stadnenko, N. M. \& Obukhovskaya, A. G. (2001). Methods of diagnosing abnormalities in the intellectual development of students. Kamyanets-Podilsky: Abetka. нями інтегруватися у суспільство та створити власне майбутнє.

За результатами даного дослідження буде визначено основні напрями та умови проведення корекційної роботи, зокрема програми занять з елементами тренінгів та ігор-драматизацій, кейсів реальних ситуацій з метою формування соціальної компетентності та соціально схваленої поведінки підлітків з інтелектуальними порушеннями.

Проведене дослідження не вичерпує всіх аспектів проблеми. Подальшого вивчення потребують питання формування комунікативних навичок учнів з інтелектуальними порушеннями, корекції особливостей їх поведінки. Крім того, дослідження повинно бути спрямоване на формування у школярів з інтелектуальними порушеннями аналізу суттєвих ознак ситуації та власних соціально схвалених переконань на основі висновків з будь-яких суджень з метою життєвого цілепокладання та успішної соціалізації у суспільстві.

\section{Список використаних джерел}

Boyle, W., Lindell, A. \& Kidd, E. Investigating the Role of Verbal Working Memory in Young Children's Sentence Comprehension. Language Learning, 63(2), 2013, pp. 211-242. DOI: 10.1111/ lang.12003

Божович Л. И. Избранные психологические труды. Проблемы формирования личности / Под ред. Д.И.Фельдштейна. М.: Международная педагогическая академия, 1995. 349 с.

Бистрова Ю. О. Забезпечення наступності в процесі професійно-трудової соціалізації осіб з вадами інтелектуального розвитку: монографія. Луганськ: “ЛНУ імені Тараса Шевченка", 2017. C. 156-217.

Спеціальна психолого-педагогічна діагностика / Под ред. Ю. О. Бистрова, В. Є. Коваленко. Харків: Майданс, 2018. 170 c.

Бистрова Ю. О., Синьов В. М. Діагностика індивідуально-психологічних рис особистості як початковий етап процесу професійнотрудової соціалізації учнів з особливими освітніми потребами. Nowoczesna edukacja: flozofa, innowacja, doświadczenie. №1. Łódź: Wydawnictwo Naukowe Wyższej Szkoły Informatyki i Umiejętności, 2019, pp. 120-129.

Choi, Y., \& Mazuka, R. Young Children's Use of Prosody in Sentence Parsing. Journal of Psycholinguist Research, 32 (2), 2003, pp. 197-217. DOI: 10.1023/A:1022400424874 


\section{Features of communication of adolescents with intellectual disabilities in the interpersonal relations}

Bystrova, Y.O. \& Sinyov, V. M. (2019). Diagnosis of individual psychological personality traits as the initial stage of the process of professional and labor socialization of students with special educational needs. Nowoczesna edukacja: flozofa, innowacja, doświadczenie. No1. Łódź: Wydawnictwo Naukowe Wyższej Szkoły Informatyki i Umiejętności.

Lozhkin, G. V. \& Povyakel, N. I. (2002). Practical psychology of conflict. Kyiv: MAUP.

Lukin, S. E. \& Suvorov, A. V. (1993). Rosenzweig drawing association test (user guide). SPb.

Pevzner, M. S. (1959). Children with intellectual disabilities: The study of children in the process of their education and upbringing. Moscow: Pedagogika.

Popovych, I. S. (2017). Psychology of social expectations of personality. Extended abstract of Doctor's thesis. Severodonetsk: Volodymyr Dahl East-Ukrainian National University.

Thomas, W. \& Kilmann, R. H. (1990). Thomas-Kilmann conflict mode instrument. XICOM.

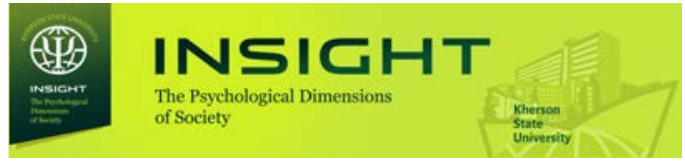

Ілляшенко Т. Д., Стадненко Н.М., Обухівська А.Г. Методика діагностики відхилень в інтелектуальному розвитку школярів. Кам'янець-Подільський: Абетка, 2001. 20 с.

Ложкин Г. В., Повякель Н. И. Практическая психология конфликта. К.: МАУП, 2002. С. 66-74. Лукин С. Е. Суворов А.В. Тест рисуночной ассоциации Розенцвейга (руководство по использованию). СПб., 1993, 62 с.

Певзнер М. С. Дети с интеллектуальными нарушениями: Изучение детей в процессе их обучения и воспитания. М.: Педагогика, 1959, $489 \mathrm{c}$.

Попович I. С. Психологія соціальних очікувань особистості : автореф. дис. на здобуття наук. ступеня докт. психол. наук: 19.00.05 “Соціальна психологія; психологія соціальної роботи”. Східноукраїнський національний університет імені Володимира Даля МOH України. Сєвєродонецьк, 2017. 40 с.

Thomas W. \& Kilmann R.H. Thomas-Kilmann conflict mode instrument. XICOM, 1990. 